\title{
RESEPSI PENONTON REMAJA FILM DUA GARIS BIRU TENTANG ISU PENDIDIKAN SEKS
}

\author{
Eklesia Ovitamaya \\ Program Studi Ilmu Komunikasi \\ Universitas Atma Jaya Yogyakarta \\ eklesiaov@gmail.com
}

Received: November 25, 2020; Revised: February 12, 2021; Accepted: February 19, 2021

\begin{abstract}
Abstrak
Film Indonesia yang mengangkat isu tentang pendidikan seks masih dianggap tabu. Pada sisi yang lain, sebagai media alternatif, pesan dalam film dapat dipahami dengan mudah oleh para penontonnya. Penelitian ini membahas resepsi penonton remaja film Dua Garis Biru tentang isu pendidikan seks. Penelitian ini menggunakan kerangka encodingdecoding Stuart Hall untuk menganalisis pemakanaan audiens dari setiap adegan dalam film. Temuan data menunjukkan bahwa audiens terbagi ke dalam tiga kelompok pembacaan: dominan hegemonik, negosiasi, dan oposisi. Posisi pembacaan penonton ini dipengaruhi oleh latar belakang dan pengalaman dari para penonton remaja. Selain itu, para penonton menginterpretasikan film Dua Garis Biru tidak hanya memberikan pesan tentang pendidikan seks, melainkan juga kesetaraan gender, nilai-nilai yang dipegang, dan bagaimana lingkungan keluarga memberikan pendidikan seks kepada para remaja.
\end{abstract}

Kata Kunci: Encoding-decoding, Film, Pendidikan Seks, Remaja, Resepsi Audiens.

\begin{abstract}
In Indonesia, movies that bring sensitive issues such as sex education was previously considered taboo. On the other hand, as an alternative media that is easily understood by the audience, movies are used as one of the most effective means of delivering messages. This study aimed to determine the reception of Dua Garis Biru's teenage audiences about sex education issues. This study used Stuart Hall's encoding-decoding analysis method to determine the audiences' meaning of each scene in the movie. The findings show that the reception of the film audience of Dua Garis Biru showed three reading positions. There were dominant reading, negotiation reading, and opposition reading. The position of the reading was highly influenced by the background and experiences of teenage audiences. Furthermore, the audiences interpret Dua Garis Biru movie as giving the messages about sex education issues but also gender equality issues, the values of the beliefs held, and how the family provided sexual education to the teenagers.
\end{abstract}

Keyword: Audiences reception, Encoding-Decoding, Movie, Sex Education, Teenagers. 


\section{Jurnal Audience: Jurnal Ilmu Komunikasi \\ Vol 04 No. 01 Tahun 2021}

\section{Pendahuluan}

Dunia semakin berkembang begitu pula dengan industri perfilman di Indonesia. Berbeda dengan tahun-tahun sebelumnya pada tahun 2015 perfilman Indonesia hanya dapat menyumbangkan sekitar $0,16 \%$ pendapatan domestik, artinya pertumbuhan dan perekembangan perfilman Indonesia belum optimal, namun pada tahun 2016 dan 2018 perfilman Indonesia mampu mengalami kenaikan dengan bertambahnya jumlah penonton Indonesia (Peningkatan, 2017).

Film domestik atau dapat disebut film lokal ini merupakan produk film yang memiliki unsur kebudayaan dengan daerah lokal tersebut dan berasal dari dalam negeri yaitu dari negara Indonesia itu sendiri. Sedangkan film nasional yaitu produk film yang memiliki unsur kebudayaan dari seluruh budaya Indonesia dan berasal dari negara Indonesia. Kini penonton dapat membanggakan film lokal yang kualitasnya sedikit demi sedikit mengejar film impor. Produksi film lokal yang meningkat ditambah dengan jumlah penonton yang bertambah setiap tahunnya menjadi pertanda kebangkitan kembali industri perfilman lokal, meski masih belum bisa mengalahkan film Hollywood maupun Bollywood.

Tak hanya itu, topik yang diusung dalam film pun mulai merambah ke ranah lain. Para pembuat film berani menuangkan kreativitas mereka dengan mengangkat topik-topik yang sebelumnya dianggap tabu namun masih dapat diterima oleh hukum dan bersifat mendidik, seperti pendidikan seks. Film ini dikemas dengan cerita dan visualisasi yang menarik, pendidikan seks tak hanya dapat diakses

di ruang kelas. Film hadir sebagai media alternatif untuk mempelajari pendidikan seks dengan memanfaatkan perkembangan zaman. Tindakan ini cukup berani, mengingat masyarakat Indonesia yang cenderung masih sensitif terhadap isu seksualitas. Hal ini merupakan tantangan yang harus dihadapi film Dua Garis Biru dalam memproduksi film berbau edukasi seksual yang dapat diterima dengan baik di masyarakat.

Pembahasan mengenai pendidikan seksual di Indonesia masih dianggap tabu. Jika menilik data, pada tahun 2007 data menyebutkan remaja laki-laki lebih banyak melakukan seks pra nikah 3,7\% dibandingkan dengan perempuan $1,5 \%$. Data ini terus mengalami peningkatan di tahun 2012 dengan presentase 4,5\% remaja lakilaki menyatakan lebih sering melakukan hubungan seks di luar nikah daripada perempuan $0,7 \%$. Dapat disimpulkan dari data tersebut, alasan remaja laki-laki $(57,5 \%)$ dan remaja perempuan (38\%) melakukan hubungan seks pra- nikah disebabkan oleh rasa penasaran atau rasa ingin tahu dan sebagian remaja lainnya $(12,6 \%)$ melakukan hubungan seks pra-nikah disebabkan oleh paksaan dari pasangannya. Hal ini mencerminkan kurangnya pemahaman remaja tentang keterampilan hidup sehat, resiko hubungan seksual dan kemampuan untuk menolak hubungan yang tidak mereka inginkan (Kementrian Kesehatan RI, 2015, h. 1).

Pada tahun 2018, Kelompok Kerja Mahkamah mencatat kasus perkawinan anak di bawah umur mencapai 193.000 kasus. Hal ini disebabkan oleh faktor ekonomi dan kurangnya perhatian dari 
keluarga. Sebanyak 14 ribu remaja (7\%) mengajukan perenungan dispensasi kepengadilan setelah melakukan hubungan pra-nikah, sedangkan remaja lainnya tidak mengajukan dispensasi dan langsung melakukan pernikahan tanpa catatan resmi (Maulidia, 2020). Hal ini terjadi karena rendahnya penggunaan alat kontrasepsi modern pada segmen usia muda (15-29 tahun). Selain itu, penyebab lainnya adalah rendahnya pengetahuan anak muda terhadap kesehatan reproduksi (KESPRO) dan kurangnya akses informasi yang akurat dan terpercaya mengenai pentingnya kontrasepsi, data ini didapatkan menurut Survey Demografi Kesehatan Indonesia pada tahun 2017 (Fikri, 2018).

Tulisan ini hendak meneliti pemaknaan (resepsi) khalayak terhadap film Dua Garis Biru yang mengusung isu pendidikan seks pada remaja. Penelitian ini dilatar belakangi bahwa film-film yang mengusung pendidikan seks kurang mendapatkan perhatian yang lebih dari masyarakat khususnya remaja karena cenderung diidentikan dengan memberi contoh yang buruk pada generasi muda atau remaja. Tidak sedikit film yang mengusung pendidikan seks ditentang oleh masyarakat, seperti film Kucumbu Tubuh Indahku dari sutradara Garin Nugroho mendapatkan protes lantaran mengangkat isu homoseksual.

Tidak hanya itu film Dua Garis Biru juga mendapatkan giliran protes akibat film ini dinilai secara gamblang menggambarkan kehamilan pra remaja, film ini menerima boikot dari masyarakat bahkan sebelum filmnya resmi tayang di bioskop (Lalita, 2019). Jika film ini ditonton secara bijak, film ini dapat berguna bagi para remaja untuk mendapatkan pendidikan yang dibutuhkan sesuai usianya. Atas dasar itu, peneliti tertarik untuk meneliti resepsi audiens terhadap film Dua Garis Biru, sebagai film yang dianggap mengusung isu pendidikan seks pada remaja. Resepsi khalayak sangat penting untuk kontroversi ini agar peneliti mengetahui perspektif khalayak dalam melihat film yang mengandung unsur pendidikan seks pada remaja.

Tulisan ini membahas tentang penonton film sebagai khalayak aktif yang memproduksi makna dalam dirinya. Oleh sebab itu, analisis resepsi cocok untuk melihat pemaknaan dari pendidikan seks yang didapat penonton dalam film Dua Garis Biru. Analisis resepsi dapat memfokuskan khalayak ke dalam tiga posisi pemaknaan yang berbeda yaitu posisi dominan, negoisasi dan atau oposisi. Khalayak dalam penelitian ini yaitu mereka para remaja yang telah menonton film Dua Garis Biru. Adapun pemilihan responden berdasarkan dari ketidaksamaan pendidikan, kebudayaan, pekerjaan, umur dan agama. Pengambilan subjek penelitian ini berdasarkan latar belakang yang berbeda bertujuan agar dapat melihat bahwa penonton bukanlah kelompok pasif, namun khalayak yang aktif. Setiap ide-ide yang disampaikan media akan mengalami dialektika dalam pikiran audiens dan memunculkan posisi pembacaannya.

Pada penelitian ini, penulis ingin menggali bagaimana pembacaan penonton remaja tentang isu pendidikan seks di film Dua Garis Biru. Penggalian informasi dari para penonton remaja nantinya bertujuan untuk melihat kerangka pengetahuan penonton remaja yang mempengaruhi cara pembacaannya terhadap ide-ide dalam film. 


\section{Kerangka Teori}

\subsection{Pendidikan Seks Remaja}

Pendidikan seks didefinisikan sebagai belajar tentang fisik, moral dan perkembangan emosi. Sementara itu, pendidikan seks dapat juga diartikan sebagai semua cara pendidikan yang dapat membantu anak muda untuk menghadapi persoalan hidup yang berpusat pada naluri seks, yang kadangkadang timbul dalam bentuk tertentu dan merupakan pengalaman manusia yang normal (Warnaen dalam Sri Esti Wuryani. D, 2008, h. 5).

Pendidikan seks adalah salah satu cara untuk mengurangi atau mencegah penyalahgunaan seks, khususnya untuk mencegah dampakdampak negatif yang tidak diharapkan seperti kehamilan yang tidak direncanakan, penyakit menular seksual, depresi dan perasaan berdosa (Sarlito Wirawan Sarwono, 2004: 188).

Pendidikan seks berguna bagi anak anak remaja, dan menolong mereka untuk menghadapi masa depannya. Pendidikan seks yang sarat dengan etika dan moral telah dilakukan oleh orangorang terdahulu melalui berbagai cara.

Pada lembaga pendidikan, pendidikan seks akan memberikan pengetahuan dasar tentang kebersihan dan perlindungan diri, dengan cara ilmiah dan medah dimengerti: menjelaskan kepada para siswa fisiologi masa puber serta perubahan psikologi dan emosi; ekspresi kelaian fisiologi seks, serta cara pengaturan diri dan bahaya yang mungkin ditimbulkan oleh perilaku seks tanpa perlindungan, menanamkan kesadaran keamanan kesadaran keamanan seks para anak serta rasa tanggung jawab mereka terhadap perilaku seks (Rasyid, 2007, Hal: 83).
Pendidikan seks bisa dikatakan sebagai salah satu bentuk pendidikan yang punya dimensi cukup kompleks dan memerlukan waktu yang cukup lama. Hasil dari suatu pendidikan juga tidak langsung dapat kita lihat hasilnya. Maka pendidikan seks sebagai aktivitas memiliki arah dan tujuan yang direncanakan dan harapannya dapat tercapai dengan baik. Tujuan itu sebagai tolak ukur keberhasilan pendidikan seks ini.

Beberapa tujuan pendidikan seks antara lain memberikan pemahaman dengan benar tentang materi pendidikan seks, menepis pandangan miring khalayak umum tentang pendidikan seks yang dianggap tabu, seronok dan non etis, pemebrian materi pendidikan seks sesuai dengan usia anak yang dapat menempatkan umpan dan papan serta mampu mengantisipasi dampak buru akibat penyimpangan seks. (Rasyid, 2007:54).

Pendidikan seks pada intinya seperti halnya pelajaran lain dalam kurikulum, berhubungan dengan transmisi informasi, memberi kontribusi pada perkembangan kemandirian seseorang serta mencari cara mensosialisasikan kelebihan diri dan masyarakat luas. Oleh karena itu, pendidikan seks memiliki muatan yang menjadi sebuah topik pembahasan yang jelas antara lain kehamilan, persalinan dan pernikahan (Manuaba, 1999: 13).

\section{Analisis Resepsi Stuart Hall}

Menurut Street (dalam Tusnawati, 2017:4) analisis resepsi adalah khalayak merupakan partisipan aktif dalam membangun dan menginterprestasikan makna atas apa yang dibaca, didengar dan dilihat sesuai dengan konteks budaya. Isi media dipahami sebagai bagian dari sebuah proses dimana common sense atau akal sehat didapat 
melalui pembacaan yang diperoleh dari gambar dan teks bahasa. Sementara, makna teks media merupakan produk interpretasi oleh penonton. Asumsinya, media hanya menjadi penyalur informasi, selanjutnya media menjadi fasilitator, penyaring dan pemberi makna sebuah informasi. Media kini bertugas untuk membawa penonton (audience) masuk dalam dunia makna yang lebih luas, tidak terbatas pada tempat dan waktu kejadian sebuah peristiwa.

Riset khlayak menurut Stuart Hall (dalam Selyi, 2018:9) dijelaskan terdapat dua perhatian langsung terhadap: (a) analisis dalam konteks social dan politik berisi media diproduksi (encoding); (b) konsumsi isi media (decoding) dalam konteks kehidupan sehari-hari. Analisis resepsi focus pada pemaknaan dan pemahaman yang lebih mendalam terhadap teks media, dan bagaimana audiens sebagai individu mengasumsikan isi media.

Menurut Hall (dalam Durham \& Kellner, 2002: 174-176) ada tiga bentuk pemaknaan antara penulis dan pembaca dan bagaimana pesan itu dibaca di antara keduanya yaitu :

1. Pemaknaan Dominan (Dominant Hegemonic Position), posisi dimana kode yang disampaikan diterima secara umum dan dimaknai secara umum dalam media, tidak terjadi perbedaan penafsiran antara produsen (penulis) dan konsumen (pembaca) pesan. Dengan kata lain, pemaknaan yang timbul sangat dekat dengan audiens. Kode yang diproduksi media merupakan hegemoni yang sering muncul atau dominan di masyarakat, yaitu berupa pandangan dominan yang merujuk pada kepentingan nasional. Dengan kata lain, pemaknaan yang muncul sangat dekat dengan audiens. Kode professional yang diproduksi media adalah hegemoni dominan yang berekembang dimasyarakat yaitu berupa ideology dominan atau merujuk pada kepentingan nasional.

2. Pemaknaan yang Dinegosiasikan (Negoitated position), kode yang disampaikan produsen berupa pesan yang ditafsirkan secara terus menerus diantara kedua belah pihak. Kode yang diterima khalayak tidak dibaca dalam pengertian umum, tetapi khalayak akan menggunakan kepercayaan dan keyakinan tersebut dan dikompromikan dengan kode yang disediakan oleh produsen pesan. Dengan pengertian lain, bahwa audiens memahami hampir sama dengan apa yang didefinisikan. Audiens dapat menolak bagian yang dikemukakan dan pihak lainnya dapat menerima bagian yang lainnya. Hall (2011:228) mengatakan decoding yang dinegosiasikan mengandung unsur yang bersifat adaptif dan oposisional: decoding tersebut mengakui legitimasi pengertian hegemonic dalam membuat signifikansi besar, sementara pada taraf yang lebih terbatas dan situasional, decoding dapat membuat aturan dasarnya sendirimelakukan pemfungsiannya dengan keberatan terhadap aturan dan perlu diperbaiki.

3. Pemaknaan oposisi (Oppositional position), pemaknaan ini terjadi ketika konsumen teks memahami dan menandakan pesan secara berbeda, teks atau kode yang disampaikan oleh produsen dengan kerangka konsep dan ideologinya. 
Dengan pengertian, bahwa audiens yang menerima pesan akan membentuk kembali dengan kode alternative secara ekstrim karena mereka memiliki pandangan yang beragam dan bermacam-macam, oleh karena itu mereka akan dapat menolak jika pesan media tidak sesuai dengan bentuk yang mereka pikirkan.

\section{Metode}

Pada tulisan ini, penulis menggunakan metode penulisan kualitatif. Metode kualitatif pada hal-hal yang bersifat diskursif seperti catatan lapangan, hasil wawancara, dokumendokumen tertulis yang kemudian dikonversikan dalam bentuk narasi yang mempunyai sifat deskriptif sebelum dianalisis, diinterpretsi dan kemudian disimpulkan (Pawito, 2007:37). Dalam pendekatan ini, penulis akan meneliti remaja secara lebih mendalam, untuk itu penelitian ini menggunakan metode wawancara untuk pengumpulan data yang dilakukan keenam responden remaja berusia 17-18 tahun yang terdiri dari tiga laki-laki dan tiga perempuan dan bersekolah di Yogyakarta serta memiliki latar belakang yang berbedabeda. Perbedaan latar belakang menjadi kunci penting dalam penelitian tentang resepsi karena dapat memberikan gambaran bagaimana pengalaman dan pengetahuan audiens berdialog dengan ide-ide yang disampaikan dalam film. Ragam latar belakang juga menunjukkan aspek-aspek ideologis yang tercermin dalam cara pembacaan audiens.

Nama dari narasumber dalam penelitian ini adalah:

1. Dyani (18) siswa homeschooling Primagama Yogyakarta mengikuti ektrakulikuler jurnalistik dan memiliki kepercayaan katolik yang kuat.

2. Manja (17) seorang siswa yang aktif dalam kegiatan sekolah nya, pernah mengikutin seminar KESPRO (Kesehatan Reproduksi) serta beragama Islam.

3. Vero (17) seorang siswa SMA Negeri 1 Depok yang memiliki hobi menonton film dan ingin mengambil jurusan Bahasa dan sastra.

4. Abel (18) merupakan siswa Homeschooling Primagama Yogyakarta, memiliki hobi menonton film terutama film yang mengangkat isu-isu kritis didalamnya seperti film Dua Garis Biru.

5. Johan (17) siswa SMA Negeri 1 Yogyakarta merupakan anggota aktif ekstrakulikuler jurnalistik serta menjabat sebagai ketua dan ingin melanjutkan pendidikannya di jurusan perfilman.

6. Irvan (17) siswa SMA Negeri 6 Yogyakarta memiliki hobi menonton film dan membuat film pendek, ia ingin mengambil jurusan perfilman atau jurnalistik serta beragama Islam.

\section{Hasil Dan Pembahasan}

Tahapan pertama melakukan resepsi yaitu menentukan encoding yang terdapat dalam film Dua Garis Biru. Hal pertama yang harus dilakukan yaitu menganalisis preffered reading dari teks untuk mengetahui pesan yang ingin disampaikan oleh pembuat pesan (Rayner, 2003:97-98). Yang selanjutnya membandingkan preffered reading tersebut dengan hasil analisis resepsi audiens (decoding) dari transkrip wawancara yang dilakukan oleh peneliti untuk kemudian audiens dikelompokan ke dalam tiga kelompok pemaknaan yaitu dominant reading, negotioated 
reading dan oppositional reading (Durham, 2002: 174-176). Terdapat 8 premis dalam adegan film Dua Garis Biru dengan isu pendidikan seks yang dipilih peneliti untuk dijadikan sebagai unit analisis dalam penelitian ini.

Poin pertama dalam pendidikan seks remaja adalah pendidikan seks menjadi salah satu cara untuk menyampaikan pesan tentang pendidikan seks pada remaja. Abel, menyatakan bahwa alasan ia menonton film Dua Garis Biru karena ingin mencari maksud dari film ini, entah pesan moral atau terdapat nilai yang bisa diambil dari film ini.

Dyani mengatakan bahwa ia penasaran terhadap pesan yang diangkat yaitu pendidikan seks, sebab pendidikan seks di Indonesia masih dianggap tabu. Irvan menyatakan alasannya karena film ini sempat menimbulkan pro dan kontra. Johan, mengatakan bahwa iya jarang melihat film dengan jalan cerita seperti film Dua Garis Biru. Manja mengantakan, asalan menonton film ini karena condong penasaran dengan topik film ini karena mengangkat tentang isu pendidikan seks. Vero menyatakan bahwa alasan ia menonton film ini karena isu sensitive yang memang jarang dibuat oleh para pembuat film di Indonesia.

Poin kedua dari pendidikan seks pada remaja adalah pendidikan seks merupakan salah satu cara untuk mengurangi atau mencegah penyalahgunaan seks seperti kehamilan yang tidak direncanakan. Proses encoding dijelaskan dalam scene film Dua Garis Biru, dimana Dara yang masih berumur 17 tahun mengalami kehamilan diluar nikah dan belum siap menjadi orang tua dengan umur yang masih muda. Abel yang merupakan anak laki-laki satu satunya dalam keluarganya memaknai scene tersebut dengan melihat sisi perempuannya dimana Dara belum siap secara fisik untuk melahirkan. Sedangkan terdapat berbedaan pernyataan dari Dyani, Irvan, Johan dan Manja mereka memaknai kesetujuannya bahwa scene diatas merupakan salah satu cara untuk mengurangi atau mencegang penyalahguanaan seks didalam pendidikan seks pada remaja. Sedangkan Vero, yang mengatakan bahwa lingkungan tempat tinggalnya memang banyak kasus remaja yang hamil diluar nikah, Vero memaknai scene tersebut dengan menyadari kalau peran orang tua itu sangat penting untuk mengajarkan anaknya tentang pendidikan seks, ia melihat bahwa Dara sebagai anak terlalu dikekang dan orang tuanya terkesan menutup akses tentang pendidikan seks.

Poin ketiga menyatakan bahwa pendidikan seks berguna bagi anak remaja dan menolong mereka untuk menggapai masa depannya. Proses encoding dari pernyataan diatas dituangkan dalam scene dimana Dara yang ketahuan hamil akhirnya harus di drop out dari sekolahnya dan tidak bisa melanjutkan pendidikannya, sedangkan Bima masih diperbolehkan melanjutkan pendidikannya dikarenakan untuk menafkahi keluarganya.

Abel mengatakan dengan sudut pandang ia sebagai laki-laki dimana ia menyatakan ketidaksetujuannya dengan Dara yang harus dikeluarkan dari sekolah karena menurutnya pendidikan dan kehamilan tidak bisa disangkut pautkan setiap orang berhak mendapatkan pendidikannya masingmasing.

Dyani menyatakan bahwa orangtuanya lah yang kurang dalam mengenalkan pendidikan seks akibatnya 
Dara harus drop out dari sekolahnya. Irvan, memaknai scene tersebut bahwa scene dimana Dara keluar dari sekolah adalah salah satu self reminder dan sebuah konsekuensi yang memang harus dipertanggungjawabkan. Johan, memaknai bahwa Dara memang salah namun kehamilan tidak menutup akses untuk dia melanjutkan pendidikannya. Manja, memaknai bahwa si Dara itu anak yang pintar dan paham akan seks namun sayang terpengaruh oleh Bima. Sedangkan Vero, memaknai mengapa hanya perempuan saja yang dirugikan padahal mereka memiliki hak yang sama dalam mendapatkan pendidikan tersebut.

Tujuan pendidikan seks dalam poin pertama dijelaskan bahwa pendidikan seks adalah salah satu upaya untuk memberikan pemahaman dengan benar tentang materi pendidikan seks antara lain memahami kehamilan dan persalinan. Proses (encoding) yang di lakukan sutradara dituangkan dalam scene dimana sutradara cukup banyak memperlihatkan adegan yang memberikan pemahaman tentang sulitnya mengandung dan resiko apa saja yang ditanggung Dara sebagai orang tua muda ketika akan melahirkan. Abel mengakatan bahwa film Dua Garis Biru sudah cukup memberikan pemahaman yang benar tentang pendidikan seks. Dyani dan Johan juga mengatakan bahwa film ini sudah menyampaikan pemahaman untuk penontonnya khususnya remaja dengan baik hanya saja film ini dirasa flat karena mungkin film edukasi, ia juga mengaku tidak kesulitan dalam menagkap pesan dan alurnya cukup tertata.

Manja dan Vero juga menyetujui bahwa film Dua Garis Biru menurut mereka sudah memberikan pemahaman yang benar tentang pendidikan seks yang ditungangkan dalam film. Berbeda dengan Irvan, yang lingkungan tempat tinggalnya cukup islami dan orang tuanya yang memberikan dasar pendidikan seks dengan berlandaskan keagamaan ia merasa bahwa film ini belum sepenuhnya memberikan pemahaman tentang materi pendidikan seks menurutnya materi pendidikan seks yang dituangkan dalam film hanya diberikan garis besarnya dan secara umum saja.

Kedua dari tujuan pendidikan seks pada remaja, pendidikan seks ingin menepis pandangan miring khalayak tentang pendidikan seks yang masih dianggap tabu, seronok dan nonetis. Proses encoding dilakukan oleh Gina S.Noer sebagai sutradara dengan membuat sebuah film Dua Garis Biru karena ingin menepis pandangan tersebut dengan mengemas film dan setiap adegannya dengan rapih dan mudah dipahami oleh penontonnya. Abel, Irvan, Johan, Dyani dan Vero memaknai bahwa film ini belum menepis pandangan miring tersebut yang artinya dengan membuat film Dua Garis Biru bukan berarti masyarakat Indonesia langsung menganggap film ini baik. Realitanya di Indonesia masih banyak yang kontra terhadap film ini. Berbeda dengan Manja, yang memiliki latar belakang pendidikan bersekolah di SMA negeri, ia mengatakan bahwa film Dua Garis Biru sudah berhasil menepis pandangan miring tentang pendidikan seks yang masih dianggap tabu, seronok dan nonetis. Alasan ia menjawab bahwa film ini sudah menepis pandangan tersebut karena pengalamannya dimana ia sebagai siswa yang ditunjuk untuk menjelaskan pada adik kelasnya setiap orientasi siswa, ia mengaku selalu menjelaskan tentang KESPRO (Kesehatan Reproduksi Remaja) dari penjelaskannya itu ia melihat film ini tidak jauh berbeda dengan apa yang 
telah ia pelajari ketika menjelaskan pada adik kelasnya.

Poin ketiga dari tujuan pendidikan seks dalam pemberian materi pendidikan seks sesuai dengan usia anak yang dapat menempatkan umpan dan papan. Proses encoding dari film Dua Garis Biru adalah memilih pemainnya sesuai dengan usia anak remaja yang menonton film ini.

Menurut pernyataan Abel, Irvan dan Manja sebagai siswa yang masih aktif disekolahnya dan juga mereka melihat dari pengalaman pemberian materi pendidikan seks di sekolah, mereka memaknai film Dua Garis Biru bahwa belum sepenuhnya memberikan materi tentang pendidikan seks pada remaja film ini hanya memberikan pembelajaran secara basic padahal pendidikan seks itu dapat jauh lebih kompleks dan tidak sesederhana di film. Berbeda dengan Dyani, Johan dan Vero, mereka memaknai bahwa film Dua Garis Biru memang sudah baik dalam menyampaikan materi pendidikan seks terlebih usia mereka sama dengan usia yang ditargetkan oleh sang sutradara.

Poin keempat dari tujuan pendidikan seks, yaitu mampu mengantisipasi dampak buru akibat penyimpangan seks. Dalam film Dua Garis Biru proses encoding dituangkan dalam scene dimana kakak Bima marah karena Bima sudah mengahili Dara. Kakak Bima mengatakan bahwa mengapa tidak menggunakan alat kontrasepsi saat melakukannya. scene ini menjelaskan bahwa ketika tidak ingin hal buruk terjadi akibat penyimpangan seks, maka harus bisa mengantisipasinya. Menurut Irvan dan Vero pesan dari scene diatas sudah benar dan menurut mereka jika suatu hal tidak ingin terjadi memang sebaiknya mengantisipasinya dengan menggunakan alat kontrasepsi. Namun, terjadi perbedaan pemaknaan dari scene diatas dimana Abel, Dyani, Johan dan Manja dimana mereka tidak membenarkan dan tidak menyalahkan scene tersebut mereka sadar bahwa alat kontarsepsi memang diciptakan untuk mencegah hal yang tidak diinginkan tapi tidak membenarkan hal yang di lakukan Bima ketika masih SMA.

Muatan pendidikan seks, dalam film Dua Garis Biru proses encoding menampilkan tiga scene yang di highlight sesuai teori muatan pendidikan seks yaitu kehamilan Dara dimana ia harus menanggung beban kehamilannya selama sembilan bulan. Kemudian, mau tidak mau kedua orang tuanya harus menikahkan mereka walaupun pada kahirnya mereka berdua memang belum siap menjadi orang tua.

Scene terakhir yaitu tentang persalinan Dara, dimana persalinan itu tidak berjalan lancar karena kehamilan di usia muda yang bersiko menyebabkan Dara harus melakukan pengangkatan rahim yang artinya Dara tidak akan bisa mempunyai keturunan lagi. Abel lebih memperhatikan soal persalinan. Abel memiliki orang tua yang berlatarbelakang seorang dokter selain itu abel juga diberikan dasardasar pendidikan seks seperti organ reproduksi, peralinan yang bersiko dan tanggung jawab menjadi orang tua, oleh karena dasar-dasar tersebut ia cenderung menayakan hal tentang persalinan beresiko ketika selesai menonton film ini.

Sedangkan Dyani, Vero dan Irvan mendiskusikan film ini yang berkaitan dengan kehamilan Dara, mereka mengatakan pacaran yang kurang sehat dan kurangnya pendidikan seks mengakibatkan Dara harus menanggung segala resikonya. Namun, berbeda 
dengan Johan, sebagai laki-laki ia lebih melihat gaya pacaran dari Bima dan Zara dan tidak melihat kearah kekehamilan, persalinan maupun pernikahan mereka. Manja sendiri, yang mendapatkan banyak masukan dari teman-temannya yang mengalami kehamilan diluar nikah mengantakan bahwa ia cenderung mendiskusikan tentang persalinan Dara dan ending setelah film ini selesai.

Pemaknaan pesan dimedia oleh penonton tidak pernah lepas dari wacana-wacana yang hadir disekitar mereka. Melihat hal itu, penulis memetakkan kecenderungan penonton remaja dalam film Dua Garis Biru yang mengangkat isu pendidikan seks dalam rentang pembacaan dominan hingga pembacaan oposisional. Pemetaan ini dilakukan tidak hanya meluhat dari sisi kuantitaif saja namun latar belakang dari informan itu sendiri terhadap isu pendidikan seks dalam film Dua Garis Biru.

1. Posisi Pembacaan Dominan

Dyani melihat kode-kode pada film Dua Garis Biru yang mengangkat isu tentang pendidikan seks ini pada posisi pembacaan dominan. Hal ini ditunjukkan dengan adanya kesamaan antara kode-kode tersebut dengan latar belakang kesehariannya. Terlebih mengenai isu pendidikan seks yang secara garis besar telah diajarkan oleh orang tuanya seperti ketika memiliki pacar untuk tidak melakukan hal-hal yang diluar batas anak remaja seperti berciuman atau pelukan. Dyani yang sejak kecil hidup dalam lingkungan keluarga yang taat pada ajaran Katolik, cukup dididik untuk tidak melakukan perbuatan seks sebelum menikah sehingga Dyani sepakat dengan pembuat film atau sutradara mengenai isu pendidikan seks yang ditungakan dalam film untuk mengingatkan para remaja untuk berhati-hati dalam menjalin hubungan di masa SMA.

Ketika Irvan menanggapi tujuan pendidikan seks pada poin keempat yang menjelaskan mampu mengantisipasi dampak buruk akibat penyimbangan seks. Menurut Irvan, ketika film Dua Garis Biru menyarankan menggunakan alat kontrasepsi, iya menyetujuinya sebab jika seorang remaja tidak mau sesuatu terjadi alangkah baiknya jika mengantisipasi dengan menggunakan alat kontrasepsi. Latar belakang pendidikan yang saat ini ia enyam juga mempengaruhi Irvan dalam menyetujui scene tersebut, ia mengatakan bahwa guru sekolahnya menyarankan akan lebih baik jika menggunakan alat kontrasepsi untuk mengantisipasi hal buruk tersebut. Selain itu, Irvan sempat mendiskusikannya dengan rekanrekannya mengenai scene yang berkaitan dengan kehamilan dan gaya pacaran yang dilakukan oleh Dara dan Bima, menurutnya sebagai anak SMA pacaran itu dirasa tidak perlu dan jangan menuruti nafsu sebab resiko yang akan ditanggung akan besar tidak hanya diri sendiri saja namun orang tua dan orang terdekat mereka.

Manja mencontohkan melalui pengalamannya sebagai siswa di SMA Negeri 6 Yogyakarta sebagai salah satu siswa yang ditunjuk untuk menjelaskan tentang kesehatan dan reproduksi pada remaja pada saat orientasi siswa baru. Dari pengalamannya ia menjelaskan bahwa kesehatan reproduksi remaja meliputi memahami pengetahuan dan masalah reproduksi remaja seperti aborsi, kehamilan dan kontrasepsi pada remaja. Hal ini menjadi tolak ukur Manja ketika memahami film ini. selain memberikan pesan pada remaja film tersebut juga mengingatkan Manja bahwa pendidikan seks penting agar ia tidak terjerumus seperti Dara, terlebih 
menurut pengakuannya dalam lingkungan pertemanannya ada kasus yang sama seperti di dalam film. Ia sempat mengatakan bahwa, temannya tersebut memberikan wejangan agar lebih berhati-hati dalam menjalin hubungan disaat usia masih remaja sebab banyak yang akan direnggut salah satunya masa depan apalagi ia adalah seorang remaja perempuan, akan lebih rentan ketika sudah melakukan hubungan badan seperti itu.

Vero merupakan anak tunggal yang dimana orang tuanya cukup keras dalam mendidik dirinya terutama soal berhubungan dengan lawan jenis. Vero ditempatkan pada posisi dominan karena ia sepakat ketika membahas mengenai poin pertama bahwa bahwa film Dua Garis Biru sebagai jembatan menyampaikan pesan tentang pendidikan seks remaja. Vero mengaku bahwa cara orang tuanya mendidik soal seksualitas yaitu dengan memberikan dasar-dasar seperti perbedaan kegunaan alat reproduksi laki-laki dan perempuan, mengenalkan resiko kehamilan dan memberi wejangan betapa sulitnya menjadi orang tua.

2. Posisi Pembacaan Negosiasi

Johan adalah salah satu informan yang menempati posisi pada pembacaan negosiasi. Hal ini dikarenakan Johan memiliki pandangan yang berbeda mengenai beberapa poin dalam adegan film yang mengangkat isu pendidikan seks. Ia mengemukakan bahwa ia memiliki pandangan yang berbeda dari beberapa poin yang sudah diberikan berdasarkan pengalam dalam didikan orang tua dan lingkungan sekolahnya.

Ketika membahas mengenai pendidikan seks remaja pada poin ketiga bahwa pendidikan seks berguna bagi anak remaja dan menolong mereka untuk menggapai masa depannya. Johan memilki pendapat sendiri tentang kegunaan pendidikan seks bagi remaja ia mengatakan bahwa dalam scene yang telah disuguhkan, sebagai remaja Dara memang salah namun, Johan mengatakan sebagai remaja laki-laki yang sudah dididik oleh orang tuanya sejak kecil dan orang tuanya mengajarkan ia bahwa pendidikan seks merupakan sebagai salah satu pedoman hidupnya kehamilan seorang perempuan tidak berarti menutup akses untuk dia melanjutkan pendidikannya.

3. Posisi Pembacaan Oposisi

Abel menjadi satu-satunya informan yang menempati posisi pembacaan oposisional. Hal ini dikarenakan Abel memilki pandangan yang berbeda dari yang lain dari keseluruhan premis yang tertuang dalam scene. Ketika membahas poin kedua dari pendidikan seks pada remaja adalah pendidikan seks merupakan salah satu cara untuk mengurangi atau mencegah penyalahgunaan seks seperti kehamilan yang tidak direncanakan. Abel memaknai scene tersebut dengan melihat sisi perempuannya dimana Dara belum siap secara fisik untuk melahirkan. Hal ini dikarenakan, latar belakang orang tua Abel yang juga sebagai dokter membuat ia sedikit paham akan pentingnya pendidikan seks seperti persalihan yang beresiko, pentingnya organ reproduksi dan bagaimana seorang anak dapat bertanggung jawab akan sebuah konsekuensi.

Abel juga memyampaikan bahwa film ini bagus, jika sebagai penonton apa lagi remaja dapat menyerap isi pesannya. Dari film ini bisa belajar bahwa setiap tindakan yang dilakukan pasti ada hal yang harus dipertanggung jawabkan, dari film Dua Garis Biru dapat memetik pelajaran bahwa apapun yang dilakukan entah hal yang menyenangkan atau tidak semua ada konsekuenmsinya. 


\section{Simpulan}

Penelitian ini menunjukkan bahwa penonton remaja merupakan khalayak aktif. Pesan-pesan yang diterima dari film Dua Garis Biru tidak disepakati mentah-mentah namun berdialektika dengan pengetahuan dan pengalaman sehingga setiap penonton remaja memiliki posisi pembacaan yang berbeda-beda. Pengaruh dari lingkungan seperti pendidikan seks dari orang tua, nilai-nilai agama yang ditanamkan, keterlibatan pada komunitas, dan informasi yang dipertukarkan dengan teman mempengaruhi cara pembacaan dari setiap penonton.

Penelitian selanjutnya diarahkan pada diskursus mengenai film-film bertemakan pendidikan seks agar dapat memberikan gambaran utuh tentang bagaimana praktik sosial mengenai pendidikan seks di Indonesia, pemetaan aktor dominan dalam pendidikan seks maupun aktof yang disubordinatkan dari isu ini.

\section{Daftar Pustaka}

Durham, Meenakshi Gigi, dan Douglas M. Kellner. 2006. Media and Cultural Studies Keywork. United Kingdom: Blackwell Publishing.

Fikri, Dimas. 2018. Angka Kehamilan Remaja di Indonesia Meningkat 500 Kehamilan Setiap Tahun, Ini Penyebabnya. Diakses https://lifestyle.okezone.com/re $\mathrm{ad} / 2018 / 09 / 25 / 196 / 1955466 / \mathrm{an}$ gka-kehamilan-remaja-diindonesia-meningkat-500kehamilan-setiap-tahun-inipenyebabnya\#: : text=Menurut $\% 20$ Survey\%20Demografi\%20 Kesehatan\%20Indonesia,persen $\% 20$ dari\%20total\%20populasi $\% 20$ Indonesia.
Kementerian kesehatan RI. 2015. INFODATIN Pusat Data dan Informasi Kemeterian Kesehatan RI Situasi Kesehatan Remaja.

Manuaba.1999. Memahami Kesehatan Reproduksi Wanita. Jakarta: Arcan.

Maulidia. (2020). Perkawinan anak di Indonesia capai 193 ribu kasus. Diakses dari nasional.okezone.com https://nasional.okezone.com/re $\mathrm{ad} / 2020 / 01 / 31 / 337 / 2161488 / \mathrm{pe}$ rkawinan-anak-di-indonesiacapai-193-ribu-kasus

Lalita, Sheila. (2019). Dua Garis Biru dan Kenyataan Pendidikan Seks di Indonesia. diakses dari Magdalene.co https://magdalene.co/story/duagaris-biru-dan-kenyataanpendidikan-seks-di-indonesia

Peningkatan pasar. (2018). Peningkatan pasar film nasional dalam mendukung industry filmIndonesia. Diakses dari investinindonesia.go.id https://www.investindonesia.go .id/id/artikelinvestasi/detail/peningkatanpasar-film-nasional-dalammendukung-industri-filmindonesia

Pawito. 2007. Penelitian Komunikasi Kualitatif , Yogyakarta: LKIS.

Rasyid, Moh. 2007. Pendidikan Seks. Semarang: Syiar Media Publishing.

Rasyid, Moh. (2007). Pendidikan Seks, Mengubah Seks Abnormal Menuju Seks yang Lebih Bermoral. Semarang, RaSAIL Media Group.

Rayner, J. (2003). Managing reputational risk. Curbing threats, leveraging 
opportunities, John Wiley \& Sons Ltd

Sri Esti Wuryani Djiwandono, 2008.

Pendidikan seks keluarga. Jakarta: PT Indeks.

Sarlito Wirawan Sarwono. 2012. Psikologi Remaja. Jakarta: PT. Raja Grafindo Persada.

Selsyi, Elisabeth. (2018). Resepsi Khalayak Terhadap Tokoh Marlina dalam Film 'Marlina $\mathrm{Si}$ Pembunuh dalam Empat Babak' dengan Perseptif Feminisme Eksistensial. Fakultas Ilmu Sosial dan Politik. Universitas Atma Jaya Yogyakarta.

Tusnawati, Risa. (2017). Analisis resepsi khalayak terhadap isi pesan pada iklan rokok u mild versi "cowo tau kapan harus bohong".Skripsi. Universitas Dian Nuswantoro. 